\title{
Cultural Affinity, Institution Stability, and Geographic Distance in Cross-Border Peer-to-Peer Micro-Lending
}

\author{
Darline Augustine, PhD \\ City University of New York \\ Northeastern University \\ Maude Toussaint-Comeau, PhD \\ Federal Reserve Bank of Chicago \\ Christopher Wheat, PhD \\ JP Morgan Chase Institute \\ Ephraim Okoro, PhD \\ Howard University
}

\begin{abstract}
International business and economic development researchers theorize that cultural affinity impacts crossborder investment decisions, but these theories produce inconclusive findings. In this study, we propose a theoretical and empirical framework that explores cross-border capital flows in a context where the effect of the levels of cultural affinity is likely to be salient for private direct investments in micro and small enterprises in developing countries. We disaggregate cross-country effects into three dimensions - culture, institutional context, and geographic distance and argue that these dimensions should have separate effects on investment. We test our hypotheses using cross-country panel data from Kiva, a peer - to-peer micro-lending platform used by investors to lend in the broad global market, and especially to developing country entrepreneurs. Our results reveal that controlling for macroeconomic and business cycle financial effects, lenders invest more in entrepreneurs that are geographically distant, have fewer socioeconomic resources, but are culturally similar. The nature and type of institutional challenges facing the borrowing country also matter.
\end{abstract}

\section{Introduction}

International business and economic development scholars and practitioners are interested in robustly understanding the extent to which the flows of foreign direct investments are facilitated and directed toward developing countries that do not generate significant internal savings to advance their economic activities. Peerto-peer lending through online platforms has emerged as a potential source of resource for economic activity. These platforms provide funding to micro and small business enterprises, with the promise to increase greater economic pluralism, including gender-based financial inclusion, which could foster economic growth and development. These new forms of social impact investment embrace the notion of "doing good while doing well" and offer an opportunity for investors to pursue profits and social investment decisions; moreover, these forums create a platform to address unresolved issues in the literature, concerning underlying factors that often influence the investment decisions of private foreign direct investors.

In this paper, we analyze cross-border capital flows in the context of foreign investment by individual lenders to micro and small business entities in developing countries, where the effect of cultural similarity and differences in levels of institutional resources are also salient. Our study builds upon a long-standing stream in international business and economic development research which has examined how cross-country similarities and differences shape the location of foreign direct investment activities (Johanson \& Vahlne, 1977; Schotter \& Beamish, 2013; Shenkar, 2001). We isolate the independent effects of economic, institutional and cultural effects in the investment decisions of private direct investors. All else equal, researchers predict that capital is most likely to flow between countries that are geographically proximate (Grosse \& Trevino, 1996; Schmitt \& Van Biesebroeck, 2013), share similar cultures and languages (Siegel, Licht, \& Schwartz, 2011), employ similar political and economic institutions (Bénassy-Quéré, Coupet, \& Mayer, 2007; Lankhuizen, de Groot, \& Linders, 2011), or share colonial or other historical ties (Makino \& Tsang, 2010). 
However, empirical tests of these claims have produced mixed results. While some studies find that foreign direct investments tend to flow across countries with similar markets (Berry, Guillén, \& Zhou, 2010; Dow \& Ferencikova, 2010; Erramilli, 1991; Grosse \& Trevino, 1996; Kogut \& Singh, 1988; Razin, Sadka, \& Tong, 2008) others find no support (Shenkar, 2001; Tihanyi, Griffith, \& Russell, 2005) or limited support (Schotter \& Beamish, 2013) for this claim.

Researchers have offered at least two sets of explanations for inconclusive empirical support for the oretical frameworks that predict foreign direct investments flow based on similarity or cultural affinity of cross-country markets. One set of theories focus on the dimensionality of cross-country differences and similarities. Many empirical studies of the effect of cross-country differences and similarities on foreign direct investment behavior (Benito \& Gripsrud, 1992; Lankhuizen et al., 2011) measure cross-country differences using a one-dimensional measure (eg., firm entry into a host country such as the United States) proposed by Kogut and Singh (1988). A number of recent studies critique this one-dimensional approach and argue that countries may vary along multiple dimensions, each of which may have an independent impact on cross-border investment decisions (Berry et al., 2010; Dow \& Karunaratna, 2006; Shenkar, 2012). These multi-dimensional conceptualizations allow for the possibility that cross-country differences produce variance on investment outcomes.

Another set of theories examines the empirical context of existing research that may obscure the effects of crosscountry differences on cross-border firm investment due to its focus on flows of capital resulting from the investment behavior of large multinational enterprises (MNEs). Large MNEs can dedicate significant resources to analyzing foreign investment decisions, and are comparatively likely to make economically large foreign investments. These firms are also more likely to face scrutiny from their own investors. As a result, large MNEs are particularly subject to strong profit-maximization norms that can significantly mute the effect of many dimensions of cross-country differences in investment decisions (e.g. Siegel et al., 2011, p. 621).

This paper contributes to the private foreign direct investment literature by attempting to shed new light on crosscountry differences as predictors of cross-border capital flows. We discuss prior studies that have disaggregated cross-country differences (Berry et al., 2010; Dow \& Karunaratna, 2006) and identify three distinct dimensions of cross-country differences: cultural similarity, differences in levels of socio-economic resources and geographic distance. Second, we explore cross-border capital flows in the context of private lenders' investments in micro and small business entities in developing countries, where the effect of cultural similarity and differences in levels of cultural resources is likely to be salient. We propose and test hypotheses using data from Kiva, a peer-to-peer micro-lending platform. The Kiva platform offers 3 key features that are relevant to this study: (a) investments in these platforms are likely to flow across borders, including (more heavily) toward developing country entrepreneurs; (b) investments are likely to be made by individual investors with sufficient discretion to be affected by cross-country differences; and (c) they have some degree of concern regarding the economic efficiency of their investments, consistent with traditional foreign direct investment premises. We explore loans funded between 2006 and 2010, a period which proceeds and includes the 2008-2010 global financial shocks, and offers strong variability in inflows of foreign capital, allowing us to isolate the global business cycle effects from investors' decisions, given their preferences. The results reveal that controlling for international macroeconomic business cycle effects, differences among countries, and opportunity maximizing motives, lenders are more likely to invest in a broader market as measured by countries that are geographically distant, and consistent with the social motives of private investors. Also, these patrons are more likely to invest in entrepreneurs in countries that have fewer socioeconomic resources but are culturally similar to theirs. After discussing these results, we conclude with a discussion of potential policy implications and directions for future research.

\section{Peer-to-peer micro-lending structure and mechanisms}

The peer-to-peer micro-lending infrastructure is a key institution through which entrepreneurial firms gain access to capital. Peer-to-peer micro-lending platforms allow individuals worldwide to identify specific entrepreneurs for investment in their enterprises.

These platforms gained prominence with the founding of Kiva in 2005 and Babyloan in 2006. Both Kiva and Babyloan incorporate traditional microfinance organizations as intermediaries that work directly with developing country entrepreneurs. 
Figure 1 below delineates the micro-loan process at Kiva. The first step involves a partnership between a Field Partner (i.e: a microfinance organization, a school, a social business or non-profit organization) and Kiva. Lenders browse loan requests on Kiva's website and select a loan to fund. Kiva aggregates funds from lenders and provides them to Field Partners for disbursement. Field Partners then collect repayments from borrowers and repay loan amounts (interest-free) to Kiva. Kiva lenders can opt to recycle loan dollars, withdraw their funds, or donate towards Kiva's operations. In Figure 1, we illustrate the process with a diagram, below.

\section{Figure 1: How Kiva Operates}

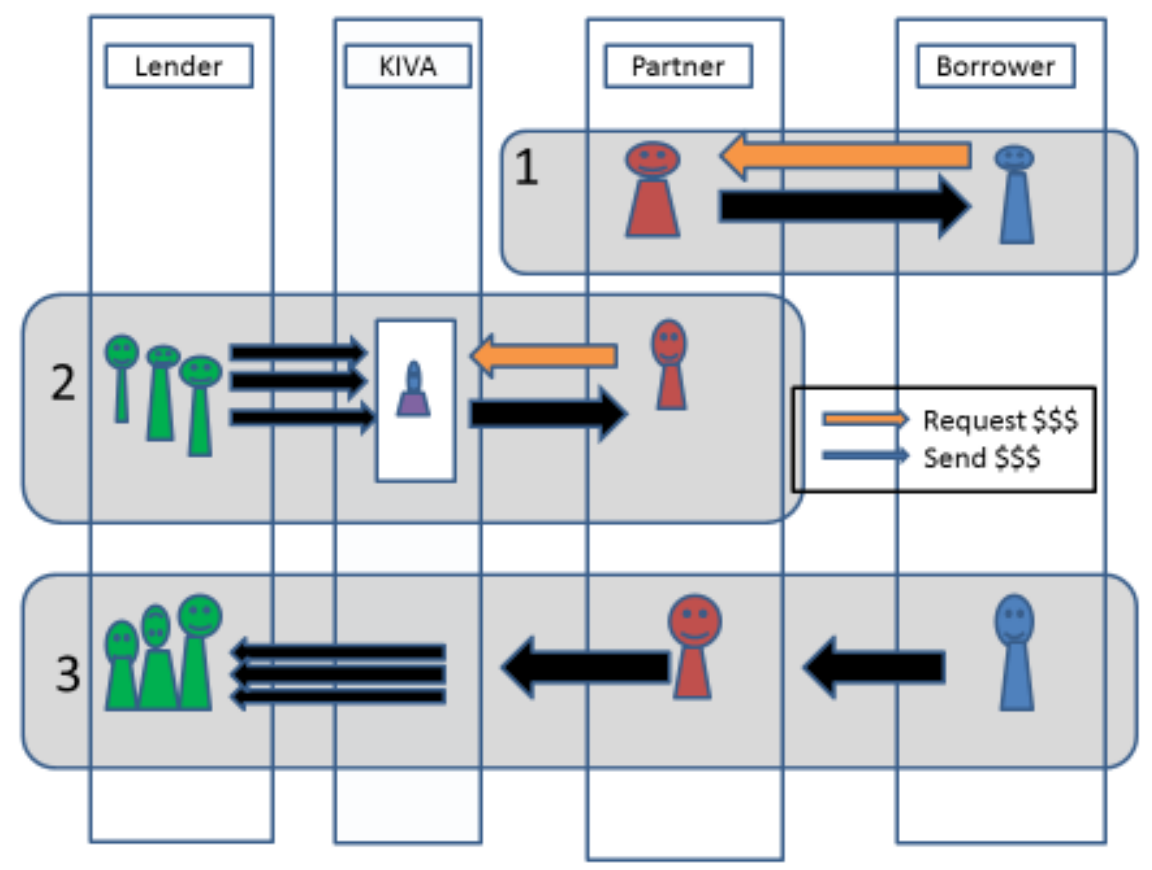

Peer-to-peer micro-lending platforms have three features that make them particularly relevant to this study. First, these platforms provide developing country entrepreneurs with access to foreign capital from a very wide range of foreign countries. Table 1 presents a complete list of the countries where lenders and borrowers who participate in Kiva's peer-to-peer microfinance platform are located, over the period of this study. Second, peer-to-peer microlending platforms offer individual investors a wide range of discretion in making investment decisions. In this sense, individual investors play a role similar to that of institutional investors in other microfinance organizations by directing flows of capital from global sources to developing country entrepreneurs (Cull, Demirgüç-Kunt, \& Morduch, 2009, p. 177).

Finally, investors who use peer-to-peer micro-lending platforms may have a broader set of motivations than traditional microfinance investors. Like other forms of microfinance, peer-to-peer micro-lending platforms espouse goals of poverty reduction and assistance to the world's poor. For example, Kiva identifies itself as "a non-profit organization with a mission to connect people through lending to alleviate poverty." 1 In addition, investors using peer-to-peer micro-lending platforms may also have concerns regarding the economic efficiency of their investments. Peer-to-peer platform lenders can identify specific entrepreneurs to provide capital to, and receive frequent information on the performance of individual loans. Figure 2 illustrates these motivations by presenting data from Kiva from a randomly selected sample of loans. Each row of the table in Figure 2 presents a description of a loan paired with the revealed motivation of the lender who provided the capital. The reasons listed are representative in that they contain both social ("We want to help people build a better life") and economic efficiency ("better "bang for the buck") rationales. 
Table 1: Lending and Borrowing Countries in Sample

\begin{tabular}{|c|c|c|c|}
\hline Borrowers: & $\begin{array}{l}\text { Afghanistan } \\
\text { Angola } \\
\text { Argentina } \\
\text { Australia } \\
\text { Austria } \\
\text { Bahamas } \\
\text { Bangladesh } \\
\text { Belgium } \\
\text { Bermuda } \\
\text { Bosnia Herzegovina } \\
\text { Brazil } \\
\text { Cambodia } \\
\text { Canada } \\
\text { Cayman Islands } \\
\text { China } \\
\text { Costa Rica } \\
\text { Croatia } \\
\text { Czech Rep } \\
\text { Denmark } \\
\text { Dominica } \\
\text { Egypt } \\
\text { Estonia } \\
\text { Finland } \\
\text { France } \\
\text { Germany } \\
\text { Greece } \\
\text { Afghanistan } \\
\text { Azerbaijan } \\
\text { Benin } \\
\text { Bolivia } \\
\text { Bosnia Herzegovina } \\
\text { Bulgaria } \\
\text { Cambodia } \\
\text { Cameroon } \\
\text { Chile } \\
\text { Colombia } \\
\text { Costa Rica } \\
\text { Côte d'Ivoire } \\
\text { Dominican Republic } \\
\text { Ecuador } \\
\text { El Salvador } \\
\end{array}$ & $\begin{array}{l}\text { Greenland } \\
\text { Honduras } \\
\text { Hong Kong } \\
\text { Hungary } \\
\text { Iceland } \\
\text { India } \\
\text { Indonesia } \\
\text { Iran } \\
\text { Ireland } \\
\text { Israel } \\
\text { Italy } \\
\text { Japan } \\
\text { Kuwait } \\
\text { Kyrgyzstan } \\
\text { Laos } \\
\text { Lebanon } \\
\text { Lithuania } \\
\text { Luxembourg } \\
\text { Macedonia } \\
\text { Malaysia } \\
\text { Malta } \\
\text { Mauritius } \\
\text { Mexico } \\
\text { Mongolia } \\
\text { Netherlands } \\
\text { New Zealand } \\
\text { Ghana } \\
\text { Guatemala } \\
\text { Haiti } \\
\text { Honduras } \\
\text { Indonesia } \\
\text { Kenya } \\
\text { Kyrgyzstan } \\
\text { Lebanon } \\
\text { Liberia } \\
\text { Mali } \\
\text { Mexico } \\
\text { Mongolia } \\
\text { Mozambique } \\
\text { Nepal } \\
\text { Nicaragua } \\
\end{array}$ & $\begin{array}{l}\text { Nigeria } \\
\text { Norway } \\
\text { Oman } \\
\text { Pakistan } \\
\text { Panama } \\
\text { Philippines } \\
\text { Poland } \\
\text { Portugal } \\
\text { Qatar } \\
\text { Romania } \\
\text { Saudi Arabia } \\
\text { Singapore } \\
\text { Slovenia } \\
\text { South Korea } \\
\text { Spain } \\
\text { Sri Lanka } \\
\text { St. Kitts \& Nevis } \\
\text { Sweden } \\
\text { Switzerland } \\
\text { Thailand } \\
\text { Trinidad \& Tobago } \\
\text { Turkey } \\
\text { Uganda } \\
\text { United Arab Emirates } \\
\text { United Kingdom } \\
\text { United States } \\
\\
\text { Nigeria } \\
\text { Pakistan } \\
\text { Paraguay } \\
\text { Peru } \\
\text { Philippines } \\
\text { Rwanda } \\
\text { Samoa } \\
\text { Senegal } \\
\text { Sierra Leone } \\
\text { Tajikistan } \\
\text { Tanzania } \\
\text { Togo } \\
\text { Uganda } \\
\text { Ukraine } \\
\text { Viet Nam } \\
\end{array}$ \\
\hline
\end{tabular}




\section{Figure 2: Lender Motivations for Providing Capital through Kiva}

\begin{tabular}{|c|c|c|c|}
\hline $\begin{array}{l}\text { Lender } \\
\text { Country }\end{array}$ & Reason & $\begin{array}{l}\text { Entrepreneur } \\
\text { Country }\end{array}$ & Loan Description (Excerpted) \\
\hline USA & $\begin{array}{l}\text { I believe this program has a } \\
\text { better "bang for a buck" than } \\
\text { other programs we have used. }\end{array}$ & Vietnam & $\begin{array}{l}\text { Thi D. is a 40-year-old married mother of two adult children living in the } \\
\text { town of Kim Động. D. joined TYM Fund in } 2003 \text { to secure a loan to help } \\
\text { grow her business and improve her living situation. Thị is now } \\
\text { requesting her 5th loan, to be used to purchase breeding livestock which } \\
\text { will help grow her business and generate additional income. }\end{array}$ \\
\hline Norway & $\begin{array}{l}\text { Something that seems small } \\
\text { to some of us, can make a } \\
\text { huge difference in others life. } \\
\text { Don't underestimate a small } \\
\text { gift! }\end{array}$ & Mexico & $\begin{array}{l}\text { Maria de los Angeles Q. is } 41 \text { years old. She only has a second grade } \\
\text { education. Maria and her family live in San Miguel Soyaltepec, Oaxaca. } \\
\text { Her husband knows how to bake and work in a bakery, but he decided to } \\
\text { start working his own business and taught her how to bake. Since then, } \\
\text { they have been working to gether in their bakery. She needs this loan to } \\
\text { buy flour, milk, sugar, sprinkles, pineapple, and butter for the bread. She } \\
\text { expects her business to prosper with the help of this loan, so that she can } \\
\text { give a better quality of life to her children and careers in the future. She } \\
\text { is very grateful to the foundation for believing in her and granting this } \\
\text { loan. }\end{array}$ \\
\hline USA & $\begin{array}{l}\text { We want to help people build } \\
\text { a better life. Kiva provides } \\
\text { the tool to bring the world } \\
\text { community together to help } \\
\text { others, this is incredible. } \\
\text { Spread the Love Folks. }\end{array}$ & Uganda & $\begin{array}{l}\text { Pelly K. is the leader of her lending group in Ntungamo. Pelly has a soda } \\
\text { depot in Rubaare Trading Centre where she offers wholesale and retail } \\
\text { services to customers. She has been in business for } 8 \text { years earning her } \\
\text { enough experience to handle her customers well. She would like to } \\
\text { expand further and use a trailer to off load instead of a truck. She needs a } \\
\text { loan to purchase soda for her inventory. }\end{array}$ \\
\hline Canada & $\begin{array}{l}\text { We believe supporting } \\
\text { women in developing } \\
\text { countries will change the } \\
\text { world. }\end{array}$ & Cambodia & $\begin{array}{l}\text { Prey Chor is a district of Kompong Cham Province. Most people live } \\
\text { there to be able to make an income by farming. Huy, age } 49 \text {, is a widow } \\
\text { and the mother of three children. She hopes to grow various crops on her } \\
\text { land. Due to lack of capital, Huy has decided to seek a loan to purchase } \\
\text { farming materials such as seeds, fertilizer and other supplies to begin } \\
\text { farming. }\end{array}$ \\
\hline $\begin{array}{l}\text { Hong } \\
\text { Kong }\end{array}$ & $\begin{array}{l}\text { I can make a difference, } \\
\text { however small. }\end{array}$ & Kenya & $\begin{array}{l}\text { Ndunyu Njeru town for the last four years. She is } 38 \text { years old, married } \\
\text { to Julius Kinyua, and the mother of one child. This will be her third loan. } \\
\text { She repaid her previous loans well within their terms, and she plans to } \\
\text { use the loan to buy } \\
\text { materials to finish a block of classrooms she is building. In the future, } \\
\text { Jane hopes to expand her } \\
\text { Kindergarten into a primary school. }\end{array}$ \\
\hline
\end{tabular}

\section{Culture, socioeconomic resources and cross-border peer-to-peer micro-lending}

The features of peer-to-peer micro-lending platforms as described show that investors who use them make investment decisions using mechanisms that are somewhat similar to those used by any other institutional investors, including to some extent, managers of transnational firms making foreign direct investment decisions. In this section, we identify a set of specific country differences that might affect investors' decisions, and we posit various sets of interrelated hypotheses regarding cross-border capital flows from individual investors to developing country entrepreneurs, drawing on existing theories and previous research on foreign direct investment inflows in developing countries that tease out the economic, institutional and cultural determinants of private investment decisions in developing countries (e.g. Dow \& Karunaratna, 2006; Johanson \& Vahlne, 1977; Kogut \& Singh, 1988; Shenkar, 2001).

Similar to other private investors, peer-to-peer platform investors may consider cross-country differences, such as: culture (Hofstede, 1980), language, education, business practices, and industrial development (Johanson \& Vahlne, 1977), political systems, religion and former colonial relationships (Dow \& Karunaratna, 2006), knowledge, financial systems, or population demographics (Berry et al.,2010)), when evaluating alternative investment opportunities.

These differences influenced private direct investment decisions of managers of transnational firms evaluating entry into foreign markets (Berry et al., 2010). Some of the cross-country differences reflect the relative positions of the country of the investor and the developing country of the entrepreneur in a vertical hierarchy. In these cases, it is meaningful to identify one country as having more socio-economic resources than another. 
For instance, comparing two countries, it is meaningful to describe one country as having a higher literacy rate, more industrial development, more patents, or a higher stock market capitalization. The variance in the levels of socio-economic resources may create frictions that impede trade (Dow \& Karunaratna, 2006) or suggest institutional differences that could impede investment (Berry et al., 2010). Within the peer-to-peer micro-lending platform, investors are generally motivated by the goal of poverty reduction, and are likely to respond not only to the size of these differences but also the direction of these differences. As a result, an investor may be more likely to make a loan when they perceive that they reside in a country that is socioeconomically more better-off than the country where the entrepreneur is located. This leads to the first hypothesis:

Hypothesis 1: Peer-to-peer platform investors will make a larger quantity of microloans to borrowers that live in countries with fewer socioeconomic resources than the country of the investor.

Other cross-country differences reflect horizontal rather than vertical distinctions. Citizens of one country make speak different languages, practice different religions, work within different political systems, or have membership in different networks of colonial relationships than do citizens of some other country. While it is plausibly meaningful to describe one country as having more literacy or economic development than another country, it is much more difficult to conceptualize the mix of languages spoken or religions practiced in one country as more or less than the mix of languages or religions in another. In this sense, distinctions between countries are more easily conceptualized as degrees of similarity than they are as relative locations in a vertical hierarchy. Accordingly, we label these horizontal distinctions as the cultural dissimilarity between a pair of countries.

Cultural dissimilarities potentially influence the decision of a private direct investor who is considering a crossborder investment in a foreign market (Xu \& Shenkar, 2002). These differences should be most salient when home country investors and host country investors are required to effectively share knowledge and otherwise coordinate resources (Carr et al., 2001). All else equal, the costs of governing joint decisions to invest across two locations with similar cultures should be lower than the governance costs faced by the investors located in locations with dissimilar cultures (Kogut \& Singh, 1988; Kogut \& Zander, 1993). Researchers have proposed a diverse set of mechanisms to account for these increased costs, including but not limited to relevant experience in a new and unfamiliar organizational context (Davidson, 1980), verification of subsidiary coordination (Head \& Ries, 2008), and differential institutional orientations (Bénassy-Quéré et al., 2007).

Overall, empirical studies attempting to link cultural differences to cross-border flows have found mixed results (Shenkar, 2001; Tihanyi et al., 2005). Several studies find a positive relationship between cultural similarity and foreign investment (Erramilli, 1991; Grosse \& Trevino, 1996; Kogut \& Singh, 1988); particularly, those that define cultural similarities in narrow and specific ways (Berry et al., 2010; Dow \& Ferencikova, 2010; Razin et al., 2008). Peer-to-peer micro-lending platform investors and developing country entrepreneurs seek to jointly address complex issues (e.g., reduction of poverty, gender inequality and other social problems). As such, lenders may be more responsive when entrepreneurs are trying to solve social issues that are culturally compatible with the lender's values. Indeed, although cultural and social mechanism effects in cross-border investments can be questioned in contexts which take as a core promise the profit-maximizing behavior of firms (Siegel et al., 2011, p. 621), it is reasonable to assume that this mechanism may be stronger in the context of peer-to-peer Microlending platform investments, where many microfinance investors explicitly espouse social goals that balance their interest in the returns on their economic investment. These arguments lead to the second hypothesis:

Hypothesis 2: Peer-to-peer platform investors will make a larger quantity of microloans to culturally similar borrowers than they will to culturally dissimilar borrowers.

Investors should also be more likely to invest in locations that are geographically proximate and less likely to invest in locations that are further away. This notion has roots in the well-established empirical literature that demonstrates that bilateral trade is more likely to occur over shorter distances than longer distances (Bergstrand, 1985, 1989), and the theoretical models that support these empirical findings (Anderson \& van Wincoop, 2003).

Empirical studies that examine the relationship between distance and foreign investment (Carr, Markusen, \& Maskus, 2001; Wei, 2000) also reveal that cross-border investments are more likely to occur between geographic proximate countries. In the context of peer-topeer- lending, we should observe investors choosing geographically investments more frequently than those that are far away. 
However, under some conditions, such as those faced by investors who use micro-lending platforms to provide capital to developing country entrepreneurs with the use of online technology, the effect of distance might be mitigated, especially in a context where cultural/language affinity also play a role.

To illustrate, the manager of the firm that identifies a foreign location with demand for a product that it currently produces would compare the profitability of a market-seeking (horizontal) cross-border investment strategy to that of continuing to produce the product in the home market and exporting it to the foreign location. Product transportation costs to distant foreign locations are higher than product transportation costs to closer foreign locations. These increased product transportation costs make exporting to distant foreign locations relatively unprofitable (Anderson \& van Wincoop, 2003; Bergstrand, 1985, 1989; Máytás, 1997). However, if the costs of establishing an affiliate in a foreign location are uncorrelated with the distance to that location, the relative benefits of establishing a foreign affiliate are greatest when the foreign market is distant rather than close (Brainard, 1997). Now, consider the peer-to-peer investor and developing country entrepreneur from the first row of Figure 2. There may well be a market demand in Vietnam for additional livestock sales. However, it is unlikely that the investor produces livestock in the US, and invested in establishing a business with a more profitable alternative to shipping livestock to a distant market in Vietnam. It is somewhat more likely that the investor identified a social problem (e.g. poverty, unemployment, gender inequality) in the foreign location. Microfinance investors face a tradeoff between travelling to a location to address a social problem directly, and investing in a developing country entrepreneur to address the same social problem. The peer-to-peer lending technological platform mitigates the personal transportation costs or the cost of physical distance, and broadens the relative benefits of investing in a developing country entrepreneur even in longer distance. This leads to the third hypothesis:

Hypothesis 3: Peer-to-peer platform investors will make a larger quantity of microloans to borrowers that are geographically close, however the costs or consideration of distance by the investor should be mitigated to the extent that culture and shared norms or values or common language is important in that decision.

\section{Research methods}

\subsection{Data}

The data used in this study comes from a wide variety of sources. We collected data on cross-border microloans by sampling individual loans from Kiva. Kiva is a dominant player in internet-based peer-to peer microfinance. The organization matches individual social investors with individual low-income entrepreneurs on a global basis (typically intermediated by partnering local microfinance institutions (see figure 1). Kiva publishes extensive data about all projects it has raised funds for through an online application programming interface. Among other things, for each loan the database indicates the country the borrower lives in, the amount of money that was actually raised, and the country of each lender. Our sample consists of 5,745 individual loans to 1,182 borrowers.

We also collect annual information on country-level characteristics in order to develop our independent variables that measure country characteristics and cross-country differences. We collected data on GDP and population from the World Bank World Development Indicators database. We collected data on country-level governance institutions from the World Bank World Governance Indicators database, and data on languages from the CIA World Factbook. We collected data on religions practiced in countries from the World Religion Dataset (Maoz \& Henderson, 2013). We collected data on colonial relationships from the Correlates of War Project data set (Correlates of War 2 Project, n.d.).

\subsection{Measures}

\subsubsection{Dependent variable}

The dependent variable in this study is the aggregate dollar amount of loans made by lenders in one country to borrowers in another country - the annual aggregate cross-border microloan flow. We construct this measure by aggregating individual estimated loan amounts by lender-borrower country pairs and year.

\subsubsection{Independent variables}

In order to assess the effect of physical distance on cross-border microfinance flows, we use the geographic distance between the country of the lender and the country of the borrower. In most cases, we compute this distance as the spherical distance between the capital city of each country. 
In cases where the capital city of a country is located far from its geographic center (e.g. the United States), we use a centrally located major city to compute geographic distance.

We use two measures to assess the level of socioeconomic resources in a country. First, we computed a measure of Industrial Development by creating a multi-item factor of measures related to the industrial development of individual countries. In order to compute an industrial development measure for all of the countries and years in our data we selected a set of individual measures from the World Bank World Development Indicators analogous to those used to create an industrial development measure by Dow and Karunaratna (2006, p. 585). Specifically, we used measures of energy use, passenger cars, mobile cellular subscriptions, telephone lines, fixed broadband internet subscriptions, internet users, manufacturing value added, GDP per capita, agricultural employment, and urban population.

As a second measure of socioeconomic resources, we computed a measure Education using an approach analogous to the computation of our Industrial Development measures. We identified a set of individual measures from the World Bank World Development Indicators most analogous to those used to create an education measure by Dow and Karunaratna (2006, p. 585). Specifically, we used measures of the adult literacy rate, secondary school enrollment and tertiary school enrollment. In both our generation of an Industrial Development measure and an Education measure, we used multiple-imputation to account for missing data in our factor analysis. Table 2 presents factor loadings and Cronbach's alpha for the individual components of each of these variables.

Table 2: Factor Loadings for Industrial Development, Education and Religion Scales

\begin{tabular}{lcc}
\hline Variables and Underlying Items & Cronbach's Alpha & Factor Loading \\
\hline Industrial Development & $0.913^{\mathrm{a}}$ & \\
Energy use (kg of oil equivalent per capita) & & 0.733 \\
Passenger cars (per 1,000 people) & & 0.834 \\
Mobile cellular subscriptions (per 100 people) & 0.581 \\
Telephone lines (per 100 people) & & 0.866 \\
Fixed broadband Internet subscribers (per 100 people) & & 0.591 \\
Internet users (per 100 people) & & 0.767 \\
Manufacturing, value added (\% of GDP) & & 0.139 \\
GDP per capital (constant 2005 US\$) & & 0.833 \\
Employment in agriculture (\% of total employment) & & -0.733 \\
Urban population (\% of total) & 0.900 & 0.703 \\
& & \\
Education & & 0.868 \\
Literacy rate, adult total (\% of people ages 15 and above) & & 0.925 \\
School enrollment, secondary (\% gross) & & 0.769 \\
School enrollment, tertiary (\% gross) & \\
Religion & & \\
Distance between major religions & & \\
Incidence of lender's major religion in borrowing country & & 0.754 \\
Incidence of borrower's major religion in lending country & & 0.940 \\
\hline
\end{tabular}

aCCronbach's alpha after items for mobile cellular subscriptions, fixed broadband internet subscribers, and manufacturing value added were dropped. A cronbach apha value higher than 0.7 is viewed as acceptable.

We used each of these country level measures of socioeconomic resources to create independent variables for the differences in socioeconomic resources between the lending and borrowing country. We calculate Industrial Development Difference as our computed Industrial Development measure for the borrowing country subtracted from our computed Industrial Development measure for the lending country.

We likewise calculate our Education Difference as our computed Education measure for the borrowing country subtracted from our computed Education measure for the lending country. These calculations generate socioeconomic resource difference measures that are positive when the lending country has more of a resource than the borrowing country, and negative when the borrowing country has more of a resource than the lending country. 
We created three measures to assess cultural similarity. Our first measure of cultural similarity is the number of languages shared between the lending and borrowing country. We base this data on languages spoken in each country reported in the CIA World Factbook. This measure does not vary over time.

Our second measure of cultural similarity is a religious distance measure. Our measure builds on time-varying data on religions practiced in individual countries from the World Religion Dataset (Maoz \& Henderson, 2013). These data place individual religions into the same four-level hierarchy used by Dow and Karunaratna (2006, p. 600). Accordingly, we were able to replicate their three religious difference items for countries in our data. The first of these measures identifies the hierarchal distance between the closest major religions in each country. This distance is smallest when two countries share a major religion at the most detailed level of the hierarchy (e.g. a denomination or sect), and it is greatest when the major religion in a pair of countries is from different families of religions (e.g. a monotheistic religion of Middle Eastern origin in a lending country and a cyclical/reincarnationbased religion of Indian origin in a borrowing country). We also compute a pair of measures that identify the incidence of a borrower's major religion in the lender's country, and the incidence of a lender's major religion in a borrower's country2. We produce a single factor variable Religious Distance based on these three items. Table 2 also presents factor loadings and Cronbach's alpha for this scale. The World Religion Dataset reports data on religious practice for one of every five years. As a result, we interpolate values for the years 2006-2009 using values from 2005 and 2010.

Our final measure of cultural similarity identifies whether a lending country and a borrowing country share a historical colonial relationship. We build this measure using data from the Correlates of War Project data set (Correlates of War 2 Project, n.d.). We use these data to create a variable Colonial Relationship that takes on a value of 1 if either the lending country were a former colony of the borrowing country, or if the borrowing country were a former colony of the lending country.

\subsubsection{Control variables}

We include an additional set of measures that identify whether the governance institutions of a country make it appear to be an attractive destination for investment (Globerman \& Shapiro, 2002). We normalize each of these five measures (stability, rule of law, control of corruption, government effectiveness, and regulatory quality) by year across the entire set of countries rated by the World Governance Indicators database.

\subsection{Model}

A key issue in modeling cross-border trade and investment flows is the treatment of pairs of countries with zero reported flow. Estimates of the importance of cross-country differences in determining microloan investment may be biased if the analysis excludes observations on the basis of the value of the dependent variable. Accordingly, we attempt to include observations of zero microloan flow between every pair of countries that was reasonably at risk of experiencing a cross-border microloan flow through Kiva. We do this by including a country as a potential source of loans in every year which anyone from that country appears as an individual lender, and including a country as a potential destination of loans in every year which anyone from that country appears as borrower. Put differently, we exclude a country pair from the analysis if, in a given year, no loans were observed originating from the lending country, and no loans were observed being made to the borrowing country.

Even with these exclusions, the sample still contains a large number of observations with no microloan flow, as is often the case with gravity model estimations. OLS models of data with this structure are inappropriate for a variety of reasons including but not limited to heteroskedastic error distributions (Head \& Ries, 2008; Kleinert \& Toubal, 2010; Santos Silva \& Tenreyro, 2006). We therefore model microloan flows using a multiplicative panel Poisson regression with robust standard errors clustered on the borrowing country, and controlling for years and countries fixed effects.

\section{Results}

Table 3 presents descriptive statistics of the dependent and independent variables used in this study. Overall, the results suggest that there is substantial variation in the level of cross-border microloan flows in this sample. Of the 7,052 country-pair years observed in the sample, 5,335 (75.7\%) have no observed flow. This significantly high number of zero values reinforced our choice to model our dependent variable using a panel Poisson regression approach. The difference between the mean Lender GDP and Borrower GDP moreover validates our claim that borrowers in our sample are likely to reside in developing countries. 
Along similar lines, the negative means for each of the borrower governance indicators indicate that in this sample, microloan borrowers are located in countries with lower than average governance scores.

Table 3: Descriptive Statistics

\begin{tabular}{lrrrr}
\hline & Mean & \multicolumn{1}{c}{ S.D. } & \multicolumn{1}{c}{ Min } & Max \\
\hline (1) Aggregate Microloan Flow & 95.359 & 720.232 & 0.000 & 19955.405 \\
(2) Log(Lender GDP) & 26.257 & 1.942 & 19.763 & 30.311 \\
(3) Log(Lender Population) & 16.472 & 1.971 & 10.867 & 21.015 \\
(4) Log(Borrower GDP) & 23.866 & 1.576 & 19.906 & 27.723 \\
(5) Log(Borrower Population) & 16.603 & 1.311 & 12.105 & 19.275 \\
(6) Log(Distance) & 8.877 & 0.735 & 4.751 & 9.903 \\
(7) Borrower Stability & -0.683 & 0.801 & -2.738 & 0.607 \\
(8) Borrower Rule of Law & -0.763 & 0.429 & -1.952 & 1.290 \\
(9) Borrower Control of Corruption & -0.686 & 0.430 & -1.624 & 1.503 \\
(10) Borrower Government Effectiveness & -0.614 & 0.443 & -1.578 & 1.180 \\
(11) Borrower Regulatory Quality & -0.418 & 0.479 & -1.686 & 1.442 \\
(12) Industrial Development Difference & 1.728 & 0.997 & 0.000 & 5.194 \\
(13) Education Difference & 1.128 & 0.732 & 0.000 & 3.466 \\
(14) Shared Languages & 0.337 & 0.533 & 0.000 & 4.000 \\
(15) Religious Distance & -0.068 & 0.920 & -2.772 & 0.721 \\
(16) Colonial Relationship & 0.013 & 0.112 & 0.000 & 1.000 \\
\hline
\end{tabular}

Table 4 presents pairwise correlation coefficients. There are two classes of variables that show high and significant correlation levels. The first are high correlations between country level GDP and population, consistent with the likelihood that countries with larger population bases on average have higher GDP. The second are high correlations among the governance measures. These high correlations likely reflect the possibility that the underlying governance constructs measured by these items may overlap.

Table 4: Pearson Correlation Coefficients

\begin{tabular}{|c|c|c|c|c|c|c|c|c|c|c|c|c|}
\hline & (1) & (2) & (3) & (4) & $(5)$ & $(6)$ & (7) & $(8)$ & (9) & $(10)$ & $(12)$ & (14) \\
\hline \multicolumn{13}{|l|}{ (1) Aggregate Microloan Flow } \\
\hline (2) Log(Lender GDP) & $0.23 *$ & & & & & & & & & & & \\
\hline (3) $\log$ (Lender Population) & $0.16^{*}$ & $0.78 *$ & & & & & & & & & & \\
\hline (4) $\log ($ Borrower GDP) & 0.02 & 0.01 & -0.00 & & & & & & & & & \\
\hline (5) $\log$ (Borrower Population) & 0.01 & 0.01 & -0.00 & $0.79 *$ & & & & & & & & \\
\hline (6) $\log ($ Distance $)$ & -0.00 & $0.03^{*}$ & $0.02 *$ & -0.01 & $-0.06^{*}$ & & & & & & & \\
\hline (7) Borrower Stability & -0.01 & -0.01 & 0.00 & $-0.28 *$ & $-0.41^{*}$ & $0.04 *$ & & & & & & \\
\hline (8) Borrower Rule of Law & -0.00 & -0.00 & 0.00 & $0.18 *$ & $0.02 *$ & 0.02 & $0.54^{*}$ & & & & & \\
\hline (9) Borrower Control of Corruption & -0.01 & -0.01 & -0.00 & $0.18^{*}$ & 0.00 & $0.10^{*}$ & $0.49^{*}$ & $0.80^{*}$ & & & & \\
\hline (10) Borrower Government Effectiveness & 0.00 & -0.00 & -0.00 & $0.53^{*}$ & $0.24 *$ & $0.07 *$ & $0.32 *$ & $0.76^{*}$ & $0.79 *$ & & & \\
\hline (11) Borrower Regulatory Quality & 0.01 & -0.01 & -0.00 & $0.42^{*}$ & $0.06 *$ & $0.06^{*}$ & $0.34^{*}$ & $0.74 *$ & $0.69 *$ & $0.82 *$ & & \\
\hline (12) Industrial Development Difference & $0.10 *$ & $0.16^{*}$ & $-0.38 *$ & $-0.16 *$ & 0.01 & $0.05^{*}$ & $-0.06^{*}$ & $-0.09 *$ & $-0.11 *$ & $-0.14^{*}-0.16^{*}$ & & \\
\hline (13) Education Difference & $0.04 *$ & $0.13^{*}$ & $-0.06^{*}$ & $-0.20 *$ & $0.12 *$ & $0.03 *$ & $-0.10 *$ & $-0.07 *$ & $-0.08 *$ & $-0.18 *-0.20 *$ & $0.46^{*}$ & \\
\hline (14) Shared Languages & $0.09 *$ & -0.02 & $0.06^{*}$ & $-0.03 *$ & $0.05^{*}$ & $-0.21 *$ & $-0.08 *$ & $0.09 *$ & $0.03^{*}$ & $0.05 * 0.03 *$ & $-0.07 *-0.00$ & \\
\hline (15) Religious Distance & $-0.04 *$ & $-0.03 *$ & $0.04 *$ & $-0.06 *$ & 0.02 & $0.16^{*}$ & -0.02 & $-0.04 *$ & $-0.14 *$ & $-0.11^{*}-0.12 *$ & $-0.04^{*}-0.01$ & $-0.06^{*}$ \\
\hline (16) Colonial Relationship & $0.03 *$ & $0.12 *$ & $0.08 *$ & $-0.03 *$ & -0.01 & -0.02 & 0.01 & $0.03 *$ & 0.01 & $0.01 \quad 0.01$ & $0.09 * 0.09 *$ & $0.10 *-0.04 *$ \\
\hline
\end{tabular}

Note: ${ }^{*} \mathrm{p}<0.05$

Table 5 reveals heterogeneity among countries within and across regions. For instance, Africa, as a region, received less investment on average than the other regional blocs (Caribbean, South America, the Middle-East and Asia). However, within the African continent, Cameroon and Benin, significantly outperformed other African countries as recipients of loan flows.

Uganda and Tanzania, on the other hand, received the least amounts in loan flows. The Middle-East and Asia and Eastern Europe received the highest micro-loan flows, and they have, on average, higher GDP. Another difference, African countries have more negative indicators of governance institutions measures in comparison to other receiving countries. Also, compared to countries in South America, language/cultural factors, is measuring smaller for African countries, although within Africa, countries such as Ghana, Cote D'Ivoire, Kenya, Liberia, Sierra Leone, and Uganda, score, relatively, higher on language/cultural similarity with the lender countries. 
Table 5: Regional Comparisons

\begin{tabular}{|c|c|c|c|c|c|c|c|c|}
\hline & $\begin{array}{l}\log \text { of } \\
\text { micro } \\
\text { loan } \\
\text { flows } \\
\end{array}$ & $\log G D P$ & stability & $\begin{array}{l}\text { rule of } \\
\text { law }\end{array}$ & corruption & $\begin{array}{l}\text { govt. } \\
\text { effectiveness }\end{array}$ & regulation & $\begin{array}{l}\text { shared } \\
\text { language }\end{array}$ \\
\hline Cameroon & 157.12 & 24.42 & -0.46 & -0.83 & -1.08 & -0.75 & -0.75 & 0.08 \\
\hline Benin & 120.63 & 21.79 & -0.25 & -0.89 & -0.99 & -1.45 & -1.45 & 0.21 \\
\hline Ghana & 79.71 & 22.42 & -0.28 & -0.40 & 0.31 & -0.11 & -0.11 & 0.58 \\
\hline Cote D'lvoire & 67.96 & 25.81 & -2.60 & -0.88 & -0.96 & -0.68 & -0.68 & 0.52 \\
\hline Kenya & 65.36 & 23.28 & -0.44 & -0.93 & -0.79 & -0.62 & -0.62 & 0.54 \\
\hline Liberia & 61.60 & 24.20 & -1.74 & -0.67 & -0.84 & -0.46 & -0.46 & 0.62 \\
\hline Mali & 59.44 & 23.64 & -0.50 & -0.42 & -0.36 & -0.58 & -0.58 & 0.02 \\
\hline Mozambique & 50.43 & 22.51 & -1.33 & -1.41 & -1.28 & -1.34 & -1.34 & 0.20 \\
\hline Nigeria & 41.25 & 23.23 & -0.24 & -0.34 & -0.57 & -0.40 & -0.40 & 0.21 \\
\hline Rwanda & 29.95 & 22.94 & 0.39 & -0.56 & -0.43 & -0.46 & -0.46 & 0.04 \\
\hline Senegal & 29.87 & 24.56 & 0.00 & -0.71 & -0.74 & -0.59 & -0.59 & 0.12 \\
\hline Slerra Leone & 25.56 & 23.75 & -0.39 & -1.13 & -0.94 & -0.83 & -0.83 & 0.52 \\
\hline Togo & 22.34 & 22.27 & -0.64 & -1.32 & -1.22 & -0.94 & -0.94 & 0.05 \\
\hline Uganda & 19.12 & 26.87 & -1.12 & -0.64 & -0.57 & -0.25 & -0.25 & 0.53 \\
\hline Tanzania & 13.43 & 26.39 & -1.49 & -0.33 & -0.39 & 0.14 & 0.14 & 0.12 \\
\hline African countries & 56.25 & 23.87 & -0.74 & -0.76 & -0.72 & -0.62 & -0.62 & 0.29 \\
\hline $\begin{array}{l}\text { Caribbean countries } \\
\text { South American }\end{array}$ & 89.75 & 22.47 & 0.08 & -0.59 & -0.75 & -0.79 & -0.79 & 0.31 \\
\hline $\begin{array}{l}\text { countries } \\
\text { other (Middle East, }\end{array}$ & 96.61 & 23.57 & -0.74 & -0.92 & -0.70 & -0.71 & -0.71 & 0.36 \\
\hline Asia) & 99.91 & 24.33 & -0.55 & -0.54 & -0.46 & -0.36 & -0.36 & 0.25 \\
\hline All receiving countries & 82.18 & 23.81 & -0.64 & -0.73 & -0.62 & -0.58 & -0.58 & 0.30 \\
\hline
\end{tabular}

\section{Empirical Results}

Table 6 presents coefficient estimates for a set of models that explore the relationship between geographic distance and aggregate cross-border microloan flows. All models show a positive coefficient for logarithmic Lender GDP and a negative coefficient for logarithmic Lender Population. This result suggests that, conditional on a positive per-capita GDP effect, there may be a negative effect of lender population on the level of cross border microloan activity. For an equivalent per-capita level of GDP, a country with a smaller population may be more likely to be the source of microloans than a country with a larger population. The positive coefficients for both logarithmic Borrower GDP and logarithmic Borrower Population suggest that a different mechanism may drive cross-border microloan activity for borrowers. Microloans appear to be more likely to flow to higher GDP countries, and even conditional on this effect, microloans appear to be likely to flow to countries with bigger populations. A bigger or more dense population should suggest more demand in a market, more profitable businesses and decreased likelihood of default, of all which might attract investors motivated by profitable investment returns.

Considerations for institutional factors reveal various nuanced tendencies for private investor decisions in crossborder direct investment, depending on the type of institutional challenges. All else equal, the results in all the models suggest that more loans still flow to countries that have indicators of government corruption and rule of law challenges. However, in the face of, lack of government effectiveness, and poor regulatory/business environment, private direct peer to peers investment is rescinded. Taken together the results of a positive effect of GDP growth and population density and institutional challenges, are consistent with the idea that these investors are at least in part interested in providing capital to address social issues of poverty and inequality, while seeking 
relatively stable and assured returns to their investment. They might seek to contribute to fill funding gaps where institutions might be weaker, but whose countries nonetheless, show some promising business prospects, and shun away in contexts of more systemic instability and high risk and regulatory contrite business environment.

Turning to the independent effects of cultural elements, models 1-6 present separate estimations of the combined impact of cultural elements, including geographic distance, socioeconomic differences, shared language and religions, and colonial/historical relationships legacies on microloan flows. Cultures and socioeconomic resources are not independently distributed across worldwide geographies. In order to partially address possible confounds between geographic and cultural/socioeconomic distance, we control for geographic distance in all presented models. Prior research also suggests that cross-country differences may have distinct components that can affect cross-border investment (Berry et al., 2010; Dow \& Ferencikova, 2010; Dow \& Karunaratna, 2006). With this in mind, Models 1-5 test individual dimensions of socio-economic resources and cultural similarity separately, while Model 6 tests the simultaneous effect of all of these components.

Table 6: Robust Poisson Estimates of Aggregate Microloan Flow

\begin{tabular}{|c|c|c|c|c|c|c|c|}
\hline & Model 1 & Model 2 & Model 3 & Model 4 & Model 5 & Model 6 & Model 7 \\
\hline \multirow[t]{2}{*}{$\begin{array}{l}\text { Control Variables } \\
\text { Log(Lender GDP) }\end{array}$} & $1.70 * * *$ & $3.48 * * *$ & $3.17^{* * *}$ & $3.51 * * *$ & $3.53 * * *$ & $1.40 * * *$ & $3.11 * * *$ \\
\hline & $(0.01)$ & $(0.01)$ & $(0.01)$ & $(0.01)$ & $(0.01)$ & $(0.01)$ & $(0.10)$ \\
\hline Log(Lender Population) & $\begin{array}{l}-0.36^{* * * *} \\
(0.01)\end{array}$ & $\begin{array}{l}-2.08^{* * * *} \\
(0.01)\end{array}$ & $\begin{array}{l}-1.91 * * * \\
(0.01)\end{array}$ & $\begin{array}{l}-2.11 * * * \\
(0.01)\end{array}$ & $\begin{array}{l}-2.12^{* * * *} \\
(0.01)\end{array}$ & $\begin{array}{l}-0.23 * * * \\
(0.01)\end{array}$ & $\begin{array}{l}-1.87^{* * * *} \\
(0.00)\end{array}$ \\
\hline Log(Borrower GDP) & $\begin{array}{l}3.19 * * * \\
(0.02)\end{array}$ & $\begin{array}{l}2.85^{* * * *} \\
(0.02)\end{array}$ & $\begin{array}{l}2.87 * * * \\
(0.02)\end{array}$ & $\begin{array}{l}2.85 * * * \\
(0.02)\end{array}$ & $\begin{array}{l}2.85^{* * * *} \\
(0.02)\end{array}$ & $\begin{array}{l}3.16 * * * \\
(0.02)\end{array}$ & $\begin{array}{l}2.85^{* * * *} \\
(0.00)\end{array}$ \\
\hline Log(Borrower Population) & $\begin{array}{l}3.15^{* * *} \\
(0.15)\end{array}$ & $\begin{array}{l}6.19 * * * \\
(0.15)\end{array}$ & $\begin{array}{l}5.71^{* * *} \\
(0.15)\end{array}$ & $\begin{array}{l}5.56^{* * *} \\
(0.15)\end{array}$ & $\begin{array}{l}5.15^{* * *} \\
(0.15)\end{array}$ & $\begin{array}{l}5.38 * * * \\
(0.15)\end{array}$ & 3.36 \\
\hline Borrower Stability & $\begin{array}{l}-0.82^{* * * *} \\
(0.01)\end{array}$ & $\begin{array}{l}-0.95^{* * * *} \\
(0.01)\end{array}$ & $\begin{array}{l}-0.93^{* * * *} \\
(0.01)\end{array}$ & $\begin{array}{l}-0.90^{* * * *} \\
(0.01)\end{array}$ & $\begin{array}{l}-0.90^{* * * *} \\
(0.01)\end{array}$ & $\begin{array}{l}-0.95 * * * \\
(0.01)\end{array}$ & -.933 \\
\hline Borrower Rule of Law & $\begin{array}{l}0.78 * * * \\
(0.03)\end{array}$ & $\begin{array}{l}1.23^{* * * *} \\
(0.03)\end{array}$ & $\begin{array}{l}0.99 * * * \\
(0.03)\end{array}$ & $\begin{array}{l}1.02 * * * \\
(0.03)\end{array}$ & $\begin{array}{l}1.02^{* * *} \\
(0.03)\end{array}$ & $\begin{array}{l}1.13 * * * \\
(0.03)\end{array}$ & .874 \\
\hline $\begin{array}{l}\text { Borrower Control of } \\
\text { Comuption } \\
\text { Borrower Government }\end{array}$ & $\begin{array}{l}0.29 * * * \\
(0.02) \\
-1.14^{* * * *}\end{array}$ & $\begin{array}{l}0.15^{* * *} \\
(0.02) \\
-1.22^{* * *}\end{array}$ & $\begin{array}{l}0.11^{* * *} \\
(0.02) \\
-1.27^{* * *}\end{array}$ & $\begin{array}{l}0.13 * * * \\
(0.02) \\
-1.23 * * *\end{array}$ & $\begin{array}{l}0.12^{* * *} \\
(0.02) \\
-1.24^{* * *}\end{array}$ & $\begin{array}{l}0.38 * * * \\
(0.02) \\
-1.11 * * *\end{array}$ & .087 \\
\hline $\begin{array}{l}\text { Borrower Government } \\
\text { Effectiveness } \\
\text { Borrower Regulatory Quality }\end{array}$ & $\begin{array}{l}-1.14^{* * *} \\
(0.02) \\
-0.44^{* * *} \\
(0.03)\end{array}$ & $\begin{array}{l}-1.22^{* * * *} \\
(0.02) \\
-0.33^{* * * *} \\
(0.03)\end{array}$ & $\begin{array}{l}-1.27^{* * * *} \\
(0.02) \\
-0.29^{* * * *} \\
(0.03)\end{array}$ & $\begin{array}{l}-1.23 * * * \\
(0.02) \\
-0.31 * * * \\
(0.03)\end{array}$ & $\begin{array}{l}-1.24^{* * *} \\
(0.02) \\
-0.32^{* * * *} \\
(0.03)\end{array}$ & $\begin{array}{l}-1.11^{* * *} \\
(0.02) \\
-0.43^{* * *} \\
(0.03)\end{array}$ & $\begin{array}{l}-1.41^{* *} \\
\text { Omitted }\end{array}$ \\
\hline \multicolumn{8}{|l|}{ Independent Variables } \\
\hline Log(Distance) & $\begin{array}{l}-0.09 * * * \\
(0.00)\end{array}$ & $\begin{array}{l}-0.10^{* * * *} \\
(0.00)\end{array}$ & $\begin{array}{l}0.11^{* * * *} \\
(0.00)\end{array}$ & $\begin{array}{l}-0.06 * * * \\
(0.00)\end{array}$ & $\begin{array}{l}-0.10^{* * * *} \\
(0.00)\end{array}$ & $\begin{array}{l}0.13 * * * \\
(0.00)\end{array}$ & $i^{.144}$ \\
\hline $\begin{array}{l}\text { Industrial Development } \\
\text { Difference }\end{array}$ & $\begin{array}{l}1.99 * * * \\
(0.01)\end{array}$ & & & & & $\begin{array}{l}1.83^{* * * *} \\
(0.01)\end{array}$ & Omitted \\
\hline Education Difference & & $\begin{array}{l}0.19 * * * \\
(0.00)\end{array}$ & & & & $\begin{array}{l}0.33 * * * \\
(0.00)\end{array}$ & \\
\hline Shared Languages & & & $\begin{array}{l}0.95 * * * \\
(0.00)\end{array}$ & & & $\begin{array}{l}0.97^{* * * *} \\
(0.00)\end{array}$ & $1.01 * * *$ \\
\hline Religious Distance & & & & $\begin{array}{l}-0.32 * * * \\
(0.00)\end{array}$ & & $\begin{array}{l}-0.20 * * * \\
(0.00)\end{array}$ & \\
\hline Colonial Relationship & & & & & $\begin{array}{l}-0.38 * * * \\
(0.01)\end{array}$ & $\begin{array}{l}-0.76^{* * *} \\
(0.01)\end{array}$ & \\
\hline Country fixed effects & No & No & No & No & No & No & \\
\hline Years fixed effects & yes & Yes & Yes & Yes & Yes & Yes & \\
\hline $\begin{array}{l}\text { Constant } \\
\ln (\alpha)\end{array}$ & $\begin{array}{r}-160.35 \\
2.42\end{array}$ & $\begin{array}{r}-213.89 \\
2.77\end{array}$ & $\begin{array}{r}-202.91 \\
2.73\end{array}$ & $\begin{array}{r}-204.98 \\
2.70\end{array}$ & $\begin{array}{r}-198.87 \\
2.65\end{array}$ & $\begin{array}{r}-188.99 \\
2.74\end{array}$ & \\
\hline Wald $\chi^{2}$ & $\begin{array}{c}1708886 \\
6514\end{array}$ & $\begin{array}{c}1692226 \\
6514\end{array}$ & $\begin{array}{c}1805838 \\
6514\end{array}$ & $\begin{array}{c}1699369 \\
6264\end{array}$ & $\begin{array}{c}1687892 \\
6514\end{array}$ & $\begin{array}{c}1848865 \\
6264\end{array}$ & \\
\hline
\end{tabular}

Models 1 and 2 provide first tests of the first part of Hypothesis 3 In both Models 1 and 2, we find negative and statistically significant coefficients for Log (Distance). These results suggest that peer-topeer micro-lending platform investors are more likely to invest in projects that are geographically closer rather than those that are geographically distant. 3

Models 1 and 2 also test the relationship between socioeconomic resource differences and crossborder loan flows. Model 1 tests this relationship for industrial development resources. The positive and statistically significant coefficient for Industrial Development Difference suggests that peer-to-peer micro-lenders are more likely to make loans to entrepreneurs in developing countries that have less industrial development than their home country. Model 2 explores a similar relationship for education. The positive and statistically significant coefficient for Education Difference likewise suggests that peerto- peer micro-lenders are more likely to make loans to entrepreneurs in developing countries that have lower levels of education than exist in their home country. Taken together, these two results provide strong support of Hypothesis 1. 
Models 3-5 test our hypothesis about the relationship between cultural similarity and cross-border micro-lending. In Model 3 we find a positive and statistically significant coefficient for Shared Languages. This result suggests that peer-to-peer micro-lenders are more likely to lend to an entrepreneur in a country where people speak similar languages than they are to invest in an entrepreneur in a country where people speak different languages. Model 4 provides a similar test for religious similarities. The negative and statistically significant coefficient for Religious Distance suggests that microfinance investors are more likely to invest in borrowers in countries where people practice similar religions than they are to invest in borrowers in countries where people practice different religions. Both of these results provide strong support for Hypothesis 2. We further test our cultural similarity hypothesis in Model 5 by exploring former colonial relationships. In this model, the negative and statistically significant coefficient for Colonial Relationship suggests that lenders are less likely to lend to borrowers in countries with which they share a colonial history than they are to lend to borrowers in countries with which they do not share a colonial history. Turning again to hypothesis 3, across the three models, the coefficient for Log (Distance) varies in sign, depending on whether or not shared language and other cultural factors are controlled for the coefficient for Log (Distance) is positive in Model 2 and 6 signaling that distance, while negatively related with investment flows is positive in a context of technology which bridges physical distance and reinforces connections through shared language and other basis of cultural affinity, when all socioeconomic resource difference and cultural similarity mechanisms are controlled for, peer-to-peer micro-lenders are more likely to provide capital to entrepreneurs in more geographically distant countries than they are to provide capital to entrepreneurs in geographically proximate countries.

The model may suffer from endogeneity bias if country-specific institutional context, which we assumed are independently determined are in fact jointly determined with cross-border investment flows. For example, it may be that a country like India where English is spoken will receive more foreign direct investment from English speaking country like the U.S., with one of the largest borrowers' base, regardless, because of a reputation and knowledge that microfinance institutions have proven to work there. If such is the case, the positive relationship between shared language and investment flow might be confounded by some country specific effect, like India. To address this set of concerns in the final model 7, we control for country fixed effects, by including a dummy for all the borrower countries in the dataset. The result suggests that the positive effects of GDP of the borrower and cultural similarity through shared language, in the investment decision of the private peer to peer lenders, remain robust to this more rigid empirical estimation procedure. But in addition, the impeding effect on foreign direct investment, of lack of government effectiveness remains also robust even in a social investment peer to peer context, irrespective of controls for countries fixed effects. This result reinforces the role of economic and cultural factors in the investors' decision to invest in cross-country investment. It also confirms previous finding for traditional foreign direct investment, which suggest that institutional stability is also a complementary and necessary element in facilitating funding to developing countries.

Using the country fixed effect model (7), we estimate the marginal effects of receiving countries specific effect on the extant of attraction of peer-to-peers investment flows (Figure 3). Controlling for all the various characteristics, the model predicts significantly positive investment flows associated with some countries in Africa, namely Benin, Mali, Mozambique, Rwanda and Senegal. 
Figure 3: Predicted Margins of Receiving Country-Specific Fixed Effects on Peer to Peer Micro-lending Flows

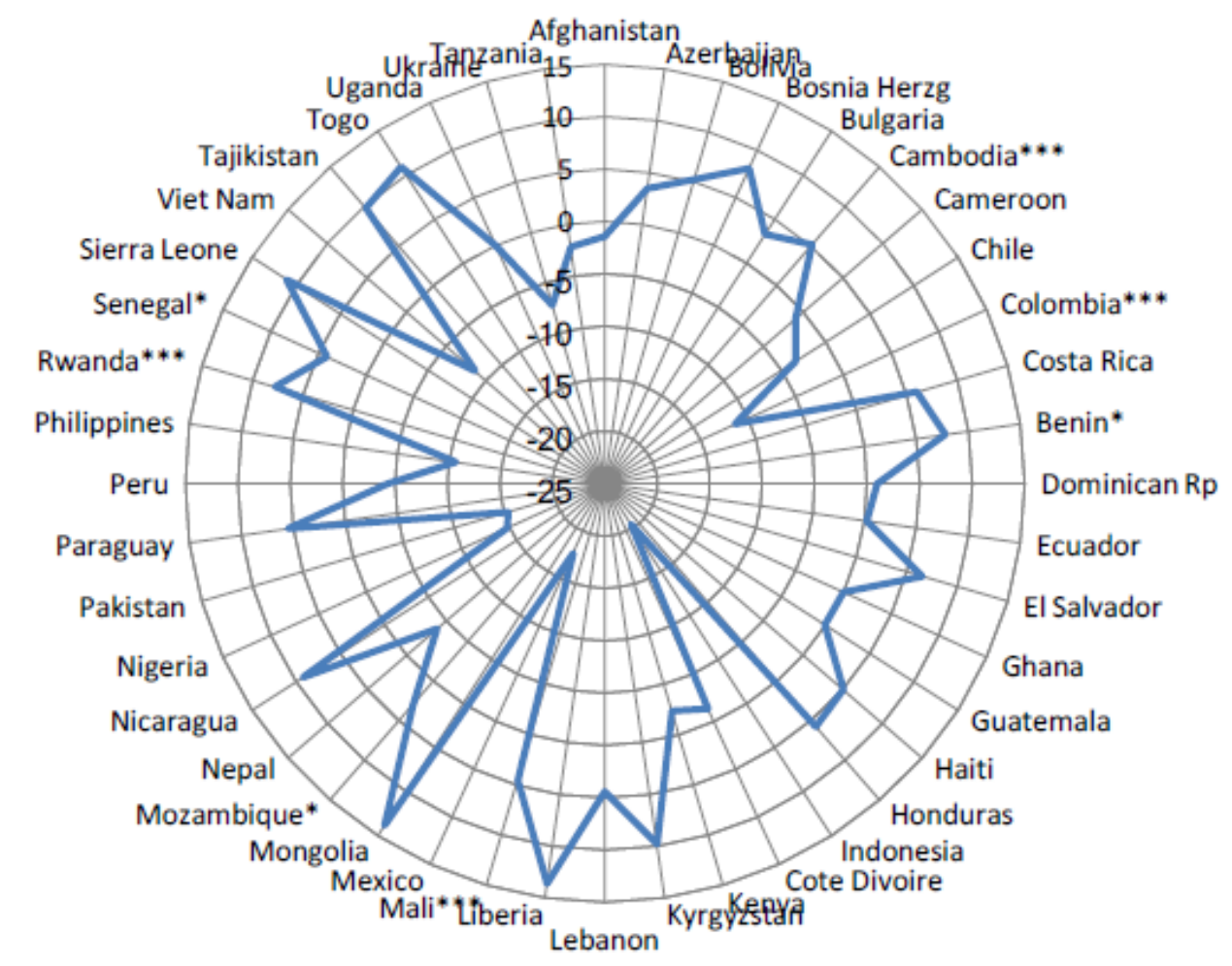

$* * *$ Significant at $.001 ; * *$ Significant at .05 . Predicted margins based on model (7).

\section{Conclusions and Implications}

The purpose of this study was to identify the effect of cross-country differences on investment flows through peer-to-peer micro-lending by using data from the Kiva platform. We hypothesized that investors are more likely to provide loans to developing country entrepreneurs that are culturally similar, have fewer socioeconomic resources, and are geographically-distant. Our results illustrate the theoretical and empirical value of examining each of these dimensions of cross-country differences separately, and broadly support each of our hypotheses.

The results from our full model provide support for each of our three proposed hypotheses. When modeled simultaneously, investors using peer-to-peer micro-lending platforms are more likely to invest in developing country entrepreneurs that are geographically distant, who live in countries with less education and industrial development, but speak similar languages and practice similar religions. While distance potentially mattersinvestors appear to have a preference to invest in countries that share cultural and language commonality; along with, considerations for the market opportunities for the investment, taking precedence in the investors' choice. In this sense, our findings suggest that lenders in our sample may be more focused on this fundamental purpose of micro-lending than other investors. This result is consistent with our conjecture that cultural and socioeconomic resources may not be uniformly distributed throughout geographic proximity. To the extent that this is true, our results are consistent with increasing calls to disaggregate the dimensions of cross-country differences as predictors of foreign investment. Independent of culture and market opportunities, countries with more institutional challenges that directly affect investment including instability and regulatory weakness might find it hard to attract investment, even if also social impact motivated.

Our study does have a number of limitations, each of which points toward a potential direction for future research. A first limitation concerns the source of our data on micro-lending organizations. In as much as we obtain these data from Kiva, our sample may not accurately reflect the broader population of micro-lending organizations. It may well be the case that investors who choose to provide loans through Kiva are systematically different than other investors currently involved in cross-border global microfinance. 
Moreover, while Kiva is a U.S. 501(c)(3) non-profit organization, and complies with all related regulations in reporting its own financial statements, the validity of our data are limited by any flaws that might exist in Kiva's reporting practices. Future researchers might productively expand on our findings by exploring data from other micro-lending platforms. An additional limitation concerns the specificity of our control variables. Our control variables attempt to account for variation in micro-lending activity that might arise from lender concern about the financial health of the developing country entrepreneur they might invest in. Our control variables are all measured at the country level, rather than at the individual or individual firm level. Future researchers might usefully expand on our study by identifying individual or firm-level measures of investment to more fully address the decision of private individual investors.

These issues notwithstanding, peer-to-peer provision of loans may play an important role in providing small entrepreneurs in developing economies access to global capital markets. The adoption of innovative ideas such as the peer-to-peer micro-lending mechanism in these emerging and developing economies is of increasing importance in international business and economic development. To the extent that policy makers and practitioners are interested in expanding access to capital markets for more credit constrained entrepreneurs, it is likely that that the structure of social relationships between providers and users of capital will need to be closely attended to, pragmatically in a context of stability and regulatory environment that makes attractive such investments. We hope that this work can serve as a step towards better understanding how private direct investment decisions (whether primarily profit or socially motivated) connect with these processes.

\section{References}

Anderson, J. E., \& van Wincoop, E. (2003). Gravity with Gravitas : A Soiution to the Border Puzzle. American Economic Review, 93(1), 170-192.

Battilana, J., \& Dorado, S. (2010). Building Sustainable Hybrid Organizations: The Case of Commercial Microfinance Organizations. Academy of Management Journal, 53(6), 1419-1440.

Bénassy-Quéré, A., Coupet, M., \& Mayer, T. (2007). Institutional Determinants of Foreign Direct Investment. World Economy, 30(5), 764-782. doi:10.1111/j.1467-9701.2007.01022.x

Benito, G. R. G., \& Gripsrud, G. (1992). The Expansion of Foreign Direct Investments: Discrete Rational Location Choices or a Cultural Learning Process? Journal of International Business Studies, 23(3), 461-476.

Bergstrand, J. H. (1985). The Gravity Equation in International Trade: Some Microeconomic Foundations and Empirical Evidence. Review of Economics and Statistics, 67(3), 474-481.

Bergstrand, J. H. (1989). The Generalized Gravity Equation, Monopolistic Competition, and the Factor- Proportions Theory in International Trade. Review of Economics and Statistics, 71(1), 143-153.

Berry, H., Guillén, M. F., \& Zhou, N. (2010). An institutional approach to cross-national distance. Journal of International Business Studies, 41(9), 1460-1480. doi:10.1057/jibs.2010.28

Brainard, S. L. (1997). An Empirical Assessment of the Proximity-Concentration Trade-off Between Multinational Sales and Trade. American Economic Review, 87(4), 520-544.

Carr, D. L., Markusen, J. R., \& Maskus, K. E. (2001). Estimating The Knowledge-Capital Model of the Multinational Enterprise. American Economic Review, 91(3), 693-708.

Correlates of War 2 Project. (n.d.). Colonial/Dependency Contiguity Data, 1816-2002. Version 3.0. Retrieved September 21, 2013, from http://correlatesofwar.org

Cull, R., Demirgüç-Kunt, A., \& Morduch, J. (2009). Microfinance Meets the Market. Journal of Economic Perspectives, 23(1), 167-192.

Davidson, W. H. (1980). The Location of Foreign Direct Investment Activity: Country Characteristics and Experience Effects. Journal of International Business Studies, 11(2), 9-22.

Dow, D., \& Ferencikova, S. (2010). More than just national cultural distance: Testing new distance scales on FDI in Slovakia. International Business Review, 19(1), 46-58. doi:10.1016/j.ibusrev.2009.11.001

Dow, D., \& Karunaratna, A. (2006). Developing a Multidimensional Instrument to Measure Psychic Distance Stimuli. Journal of International Business Studies, 37(5), 578-602.

Dunning, J. H. (1998). Location and the Multinational Enterprise: A Neglected Factor? Journal of International Business Studies, 29(1), 45-66.

Erramilli, M. K. (1991). The experience factor in foreign market entry behavior of service firms. Journal of International Business Studies, 22(3), 479-501.

Ghoshal, S., \& Bartlett, C. A. (1988). Creation, adoption, and diffusion of innovations by subsidiaries of multinational corporations. Journal of International Business Studies, 19(3), 365-388. 
Globerman, S., \& Shapiro, D. (2002). Governance infrastructure and US foreign direct investment. Journal of International Business Studies, 34(1), 19-39. doi:10.1057/palgrave.jibs.8400001

Grosse, R., \& Trevino, L. J. (1996). Foreign direct investment in the United States: an analysis by country of origin. Journal of International Business Studies, 27(1), 139-155.

Hart, S., \& Prahalad, C. K. (2002). The Fortune at the Bottom of the Pyramid. Strategy+Business, 26(1), 54-67.

Head, K., \& Ries, J. (2008). FDI as an outcome of the market for corporate control: Theory and evidence. Journal of International Economics, 74(1), 2-20. doi:10.1016/j.jinteco.2007.04.004

Hofstede, G. (1980). Culture's consequences: International differences in work-related values. Beverly Hills: Sage Pubications.

Johanson, J., \& Vahlne, J.-E. (1977). The Internationalization Process of the Firm-A Model of Knowledge Development and Increasing Foreign Market Commitments. Journal of International Business Studies, 8(1), 23-32.

Kleinert, J., \& Toubal, F. (2010). Gravity for FDI. Review of International Economics, 18(1), 1-13. doi:10.1111/j.1467-9396.2009.00869.x

Kogut, B., \& Singh, H. (1988). The effect of national culture on the choice of entry mode. Journal of International Business Studies, 19(3), 411-432.

Kogut, B., \& Zander, U. (1993). Knowledge of the Firm and the Evolutionary Theory of the Multinational Corporation. Journal of International Business Studies, 24(4), 625-645.

Lankhuizen, M., de Groot, H. L. F., \& Linders, G.-J. M. (2011). The Trade-Off between Foreign Direct Investments and Exports : The Role of Multiple Dimensions of Distance. World Economy, 34(8), 1395-1416. doi:10.1111/j.1467-9701.2011.01335.x

Ly, P., \& Mason, G. (2011). Competition Between Microfinance NGOs: Evidence from Kiva. World Development, 40(3), 643-655. doi:10.1016/j.worlddev.2011.09.009

Makino, S., \& Tsang, E. W. K. (2010). Historical ties and foreign direct investment: An exploratory study. Journal of International Business Studies, 42(4), 545-557. doi:10.1057/jibs.2010.53

Maoz, Z., \& Henderson, E. A. (2013). The World Religion Dataset, 1945-2010: Logic, Estimates, and Trends. International Interactions, 39(3), 265-291. doi:10.1080/03050629.2013.782306

Máytás, L. (1997). Proper Econometric Specification of the Gravity Model. World Economy, 20(3), $363-368$. doi:10.1111/1467-9701.00074

Morduch, J. (1999). The Microfinance Promise. Journal of Economic Literature, 37(4), 1569-1614.

Mowery, D. C. (2008). Plus ca change: Industrial R\&D in the "third industrial revolution." Industrial and Corporate Change, 18(1), 1-50. doi:10.1093/icc/dtn049

Nachum, L., \& Zaheer, S. (2005). The persistence of distance? The impact of technology on MNE motivations for foreign investment. Strategic Management Journal, 26(8), 747-767. doi:10.1002/smj.472

Prahalad, C. K. (2010). The Fortune at the Bottom of the Pyramid: Eradicating Poverty Through Profits. Upper Saddle River, New Jersey: Prentice Hall.

Razin, A., Sadka, E., \& Tong, H. (2008). Bilateral FDI flows: threshold barriers and productivity shocks. CESifo Economic Studies, 54(3), 451-470. doi:10.1093/cesifo/ifn025

Santos Silva, J. M. C., \& Tenreyro, S. (2006). The Log of Gravity. Review of Economics and Statistics, 88(4), 641658. doi:10.1162/rest.88.4.641

Schmitt, A., \& Van Biesebroeck, J. (2013). Proximity strategies in outsourcing relations: The role of geographical, cultural and relational proximity in the European automotive industry. Journal of International Business Studies, 44(5), 475-503. doi:10.1057/jibs.2013.10

Schotter, A., \& Beamish, P. W. (2013). The hassle factor: An explanation for managerial location shunning. Journal of International Business Studies, 44(5), 521-544. doi:10.1057/jibs.2013.7

Shenkar, O. (2001). Cultural Distance Revisited: Towards a More Rigorous Conceptualization and Measurement of Cultural Differences. Journal of International Business Studies, 32(3), 519-535.

Shenkar, O. (2012). Cultural distance revisited: Towards a more rigorous conceptualization and measurement of cultural differences. Journal of International Business Studies, 43(1), 1-11. doi:10.1057/jibs.2011.40

Siegel, J. I., Licht, A. N., \& Schwartz, S. H. (2011). Egalitarianism and international investment. Journal of Financial Economics, 102(3), 621-642. doi:10.1016/j.jfineco.2011.05.010

Tihanyi, L., Griffith, D. A., \& Russell, C. J. (2005). The effect of cultural distance on entry mode choice, international diversification, and MNE performance: a meta-analysis. Journal of International Business Studies, 36(3), 270-283.

Wei, S.-J. (2000). How Taxing is Corruption on International Investors? Review of Economics and Statistics, 82(1), 111.

$\mathrm{Xu}$, D., \& Shenkar, O. (2002). Institutional distance and the multinational enterprise. Academy of Management Review, 27(4), 608-618. 